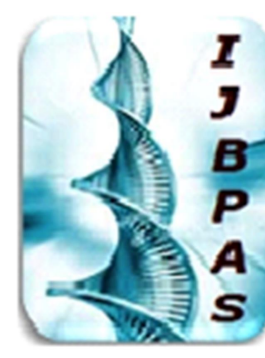

International Journal of Biology, Pharmacy and Allied Seiences (IJBPAS) 'A Bridge Betusen Caboratory med QRendo' Www.ijbpas.com

\title{
DASHMOOLA -AGRO TECHNIQUES
}

\section{MOHITE $\mathbf{P}^{1 *}$ AND UTKAR $\mathrm{S}^{2}$}

1: Final year PG Scholar, Department of Dravyaguna Vigyana, Parul Institute of Ayurved, Parul University, At Post Limda, Tal. Waghodia, Dist. Vadodara 391760, Gujarat, India

2: Associate Professor, Department of Dravyaguna Vigyana, Parul Institute of Ayurved, Parul University, At Post Limda, Tal, waghodia, Dist. Vadodara 391760, Gujarat, India

*Corresponding Author: Priya Mohite

Received 12 ${ }^{\text {th }}$ Dec. 2021; Revised 14 ${ }^{\text {th }}$ Jan. 2022; Accepted $7^{\text {th }}$ Feb. 2022; Available online $5^{\text {th }}$ March 2022

https://doi.org/10.31032/IJBPAS/2022/11.3.1053

\section{ABSTRACT}

Dashmoola, as name indicates the combination of ten magical roots which is most extensively used by Ayurvedic practitioner. As $90 \%$ of Indian medicinal system contains the formulations of AYUSH department among them Dashmoola is one of the main formulations. Demand for raw material of Dashmoola drugs from Ayurvedic industry currently is many times more than the raw material actually available. In clinical practice we hardly get 3-4 drugs of the Dashmoola which is identified. According to the IUCN (International Union for Conservation of Nature) Red list of drug, among Dashmoola, Bilva (Aegle marmelos Linn) and Shalaparni (Desmodium gangeticum Linn) are near threatened, Shyonak (oroxylum indicum Linn) is vulnerable ${ }^{1}$. For the solution of this problem NMPB (National Medicinal Plant Board) has promoting the proper development of Agro techniques for different medicinal plant, which will be for proper conservation and sustainable use of drug. So here in this study we are going to focus on different agro techniques of Dashmoola group plant mentioned by NMPB. This board is also giving Subsidies for cultivation of medicinal plants.

Keywords: Dashmoola, Agro techniques, IUCN, NMBP 


\section{INTRODUCTION}

Dashmoola, dash -ten, moola- roots combination of drugs which contains ten roots. Brihatpachamoola i.e. Bilva, Agnimantha, Shyonaka, Patala and Gambhari, and Laghupanchamula include Brihati, Kantakari, Prshniparni, Shalaparni, and Gokshura. It acts on all Tridosha (vata, pitta, kapha) ${ }^{2}$. According to Ayurveda it has wide spectrum of action. In charak samhita, it has explained under Shwayatu (Edema) Mahakashya ${ }^{3}$ and In Sushruta Samhita Mentioned under Swasahara (used in breathing disease), Tridoshghna ( pacifies all three Doshas), Amapachana (Digestion of Ama), Sarvajwarahara (Useful in all fevers $)^{4}$. Dashmoola is part of many well known classical formulations like Chavanyanprash, Dashmoolarishta,

Dashmoola haritaki for preparation of such formulations Moola Twaka (Root bark) of Brihatpanchmoola and Moola (Root) of Laghupanchmoola are required ${ }^{5}$. This is causing the exploitation of the big trees which mainly include Brihatpanchmoola. Scarcity and increased demand of raw materials of Dashamoola, Causing the adulteration and substitution of unauthentic drugs. Many herbal pharmaceutical company available in market don't even care about the standardized preparation of herbal product, rarely manufacturer are following the classical SOP (Standard operating procedure) for preparation formulations. So to overcome this problem NMPB (National Medicinal Plant Board) has given the agro techniques different medicinal plant. Here we are going to focus on the Agro techniques Dashmoola group drugs.

\section{METHODS}

The IUCN (International Union for Conservation of Nature) Red List

\section{Bruhat pancham}

1. Bilwa (Aegle marmelos Corr. / FamRutaceae/ Bael fruit) Planting materials: Seeds

\section{Nursery preparation:}

Seedling preparation: Seeds are collected then sown in the soil in the month of Febmarch within 15 days germination will take place. Seedlings become ready for transplanting in spring. Seeds shouldn't sown deep as it delays the germination. It can also sow in polythene bags. Seeds are sown in water for 10-12 hrs for better germination.

\section{Plantation on the field:}

Land preparation and fertilizer: For Bilva plantation, soil should be sandy and slightly loamy. Pits should be tilth so soil will become fine. Dug 90x90x90 cm pith then add neem oil and bone dust of required quantity. 
Watering should be done so soil get settle. Transplanting and spacing: transplantation done with spacing of $10 \times 10 \mathrm{~m}$. Harvesting: Harvesting should be done in the month of January when the fruits are turning towards yellow color and it can be kept like this for 8 days then flesh is collected Seeds are dried and stored ${ }^{6}$.

2. Agnimantha (Premna mucronata RO/ Fam- Verbenaceae) Planting materials: Seeds

\section{Nursery preparation}

Seedling preparation: Seed should be sow in seedling tray after. As the seed cover is so much hard, it should be soaked in water for 3days.with this procedure seed germination get improved by $70-80 \%$. About $100-120$ gm seed can be used to raise plants for one hectare of land. Vegetative propagation should be started in june-july month.

\section{Plantation on the Field:}

Land Preparation and Fertilizer: The land is cleaned by of weeds plants and vegetation and ploughed can be done twice by which soil get loose. Then left land as it is for 10 days then ploughed. Transplantation of plants: Plants grown in seedling tray are ready for transplantation after about $70-80$ days when they acquire 5-7 leaves and become $25 \mathrm{~cm}$ tall. Transplantation at this stage has shown that seedling get hamper so it has to kept in polybags only so the growing rate will get increase. Almost 500 plants are needed for one hectare area. Harvesting can be done when plants start bearing flowers and fruits after 4 years. Trees from 8 years onwards only show mature bark. Pleeling of bark is avoided during flowering and fruiting season and in rainy season ${ }^{7}$.

3.Shyonak ( Oroxylum indicum Linn / fam Bignoniaceae) Planting materials: seeds Nursery preparation Seedling preparations: for Shyonak plantation seedlings should be prepared. Seeds sown in the month of February in the polythene bag. For seed germination sandy loamy soil required. Add FYM in to soil for better germination.

Preparatory measures: About $250 \mathrm{~g}$ of seeds are required for plantation in one hectare land. To increase the germination rate seeds can be soken into water for 1day.

\section{Planting in the field}

Land preparation and fertilizer application:

The land is cleaned to make it porous, weed less, free from insects. Pits sixe should be 60 $\mathrm{cm} \times 60 \mathrm{~cm} \times 60 \mathrm{~cm}, 10 \mathrm{~kg}$ FYM required for planting the tree, and the pit is loosely filled back before planting. Transplanting and optimum spacing: in the month of June transplanting should be done. A spacing of $2 \mathrm{~m} \times 2 \mathrm{~m}$ should be done. 2500 plants required for the 1 hectare land 
Harvesting: The tree starts flowering and fruiting into 3 years. Only roots bark is collected after 8 years of tree maturity, the roots are thoroughly cleaned, peeling of barks is done and dried into the shade ${ }^{8}$.

4. Patala (Stereospermum colis Dillw./ famBignoniaceae) Planting materials - seeds

\section{Nursery preparation Preparatory}

measures: For plantation of Patala tree whole capsule is collected and dried for one week in shade. The seeds are removed from the dry capsule. The viability of seed remains for two months and declines gradually and lost after $5^{\text {th }}$ month of harvest. Seeds are sown immediately into germinator. The seed germination occurs into 6 to 20 days and the germination is completed within 8-15 days.

Preparation of Seedlings: Plants remain in polybags for about 8 months before transplanting into the field in rainy days. Little amount of irrigation should be done and shade required for growth.

Planting in the Field: Land Preparation and fertilizer: About one year old plant height of $70-80 \mathrm{~cm}$ is ready for transplantation. Best time for field planting is last week of May. Transplanting and Optimum Spacing: Pits of $30 \mathrm{~cm} \times 30 \mathrm{~cm} \times 30 \mathrm{~cm}$ are dug at a distance of $10 \mathrm{~m}$ between rows. About 330 plants are needed in one hectare. It attains a height of $15-20 \mathrm{~m}$ then planting is done. Harvesting techniques: roots can be harvesting after five years. Roots are dried in shed and stored in gunny bag 9 .

5. Gambhari (Gmelina arborea Roxb. / FamVerbenaceae)

Planting material: seeds

Nursery Technique Breeding technique: Gambhari is very demanding free deemed light require for plantation. Nursery bed prepared for germination. Seeds germinate within in 20-25 days. Weeding and watering is should be done when required.

Preparatory measures: To increase the rate of germination seeds can be soken into plan water. Small amount of warmth required for germination, so tray should be covered with layer of hay.2000- 2500 seeds needed for the 1 hectare area.

Planting in the Field: Land Preparation and Manure Application: The land is prepared before plantation by way of removing the weeds, insects. Pits of $45 \mathrm{~cm} \mathrm{x} 45 \mathrm{~cm} \times 45$ $\mathrm{cm}$ of size are dug during the month of May at a spacing of $4 \mathrm{~m} X 4 \mathrm{~m}$. The pits are filled with Farm Yard Manure (FYM), plantations is done in the month of June-July in $1^{\text {st }}$ week of the rainy season. Transplanting and Optimum Spacing: About $10-15 \mathrm{~cm}$ tall plants are transplanted in pits, The required spacing between plant to plant $\begin{array}{lllll}\text { should be } 4 \mathrm{~m} & \mathrm{X} & 4 \mathrm{~m}\end{array}$ 
Harvesting: As plant grow very fast so harvesting can be within 7 days ${ }^{10}$.

6. Brihati (Solanum indicum Linn / Famsolanaceae)

planting material: seeds

\section{Breeding technique and planting measure:}

Seedling can be raised in nursery in MayJune. 1 to 1 and half old seedlings are planted in the field. July to august month is good for the sowing; direct seed can be sown in land. Seed is sown in nursery beds in the month of June in shady areas. Approximately $4 \mathrm{~kg}$ of seeds are required 1 hectare of land. No presowing treatment of seeds is required for plantation.

Planting in the field Land preparation and fertilizer

application

Land preparation should be done in June before rains season. Land should be ploughed well and weeds are removed. Water stagnation should be avoided. 5 tones of FYM needed for 1 hectare area. The FYM should be properly mixed with the soil before rains season.

Transplanting and optimum spacing: $20-30$ days are required for complete germination. A spacing of $30 \mathrm{~cm} \times 30 \mathrm{~cm}$ in the field is optimum for good growth and increase productivity of crop. The optimum crop stand is about 1 lac trees/hect
Harvesting: best time for harvesting is April, collection of fruits are done dried in the shade. Roots dog out manually, dried and stored ${ }^{11}$.

\section{Kantakari (Solanum surattense Burm.} /Fam- Solanaceae / Wild Eggplant)

Planting material: Seeds

\section{Nursery preparation}

Breeding technique: Kantakari is grown through sowing of seeds. Seeds take 10-15 days for germination. Generally nursery beds are prepared for seedling preparation. A layer of well decomposed farmyard manure is spread over top soil of the nursery bed. The seeds are sown around 15 June in, at a distance of $7.5 \mathrm{~cm}$ at $0.5-1.0 \mathrm{~cm}$ dept between plant. Light watering is required daily.

Preparatory measure: About, 1.25 to $2.5 \mathrm{~kg}$ seeds are needed for growing for 1 hectare plantation. Seeds are soaked in water for 24 hrs show fast germination.

\section{Planting in the Field}

Land Preparation and Fertilizer: The land is ploughed, harrowed and weeds are removed. Well decomposed application of FYM for proper growth of plant. Transplanting and Optimum Spacing: The seedlings are ready for transplanting within 10 to 12 days. It is ready for transplantation when 4-6 leaves appearance and height up to $10-12 \mathrm{~cm}$. 
Watering should be with held 3-4 days in nursery before transplanting so that seedlings get hardened. Complete harvesting of the crop can be done in 5 years ${ }^{12}$.

8. Prshniparni (Uraria picta Desv/Fam Fabaceae)

Planting material: Seeds collected in December and January

Nursery preparation:

Breeding technique: Prshniparni is grown through sowing of seeds in the seedling tray; in the month of may-June. Very light amount of water is needed but regularly should be given, within 10 days germination will take place. 60-70days will be needed for complete germination.

\section{Preparatory measures:}

About, 4-5 KG seeds are needed for growing about 1 lakh Seedlings for 1 hectare plantation. 24 hrs soaking of seeds in water before sowing improves germination rate. Plantation on the land:

Land preparation and fertilizer. Land preparation and fertilizer application Proper drainage should be ensured in the field to avoid water logging, which causes death of plants.

\section{Transplanting and optimum spacing:}

Transplanting of 50-60-day-old plant is done in the well-prepared field on ridges. About 1lac saplings are required in 1 hectare of land at an optimum spacing of $30 \mathrm{~cm} \times 30 \mathrm{~cm}$.

Harvesting: Roots can be harvested in December or may after flowering, dried and stored. $^{13}$

\section{Shalaparni (Desmodium gangeticum} Linn /Fam-Fabaceae) Planting material: Seeds

\section{- Nursery preparation:}

Breeding technique: Shalaparni is grown through sowing of seeds in the seedling tray, with adding of soil, sand and FYM (farmyard manure). Within 7-8 days seeds get germinate and after 45 days it will get ready for transplant.

Preparatory measure: About, 3-5 KG seeds are needed for growing about 50000 seedlings for 1 hectare plantation. Seeds are soaked in water for 12 hrs show fast germination.

\section{Planting on the land}

Land preparation and fertilizer: The field should be prepared well by giving one ploughing and two harrowings, followed by planking. Manure at the rate of 10 tones/ hectare should be mixed thoroughly with the soil at the time of field preparation. Transplanting: Transplantation of seedling in irrigated farms should be done after 60 days. Space between plants: per hectare 1 lakh 
seedlings needed and about $30 \times 30 \mathrm{~cm}$ spacing should be done.Harvesting should be done after 10 months, probably in may- June. Whole plants dried in the shade. Then roots are separated from the plant and clean. Store in Humid -free environment ${ }^{14}$.

10. Gokshura (Tribulus terrestris Linn/FamZygophyllaceae/Land-Caltrops) Planting material: Seeds

\section{Nursery preparation:}

Breeding technique: Gokshura is grown through direct sowing of seed

Preparatory measures: Approximately 1$2 \mathrm{KG}$ seeds are required for growing in one hectare land. For increase germination of seeds has to be soken in water for overnight.

\section{Plantation in land}

Land Preparation and Fertilizer: Land is prepared by giving one cross sloughing and harrowing then by planking.

Space between plants: per hectare 6000 plants about 90x120 cm spacing should be done. 30days will take for full germination.

Harvesting should be done after 240-250 days. Seeds ripen in October then plants are uprooted. Roots are dried and stored in air tight container ${ }^{15}$.

\section{- DISCUSSION}

The raw materials of many medicinal plant are collected from the natural habitat however plant materials collected from these sources may lead to the adulteration and misidentification due same morphological characteristic features just like Agnimantha (Premna mucronata) adulterated with p.corymbosa ${ }^{16}$, Shyonak with Aralu (Alianthus excelsa Roxb) ${ }^{17}$, Patala (Stereospermum suaveolens DC) or (s.colis) with khadashingi

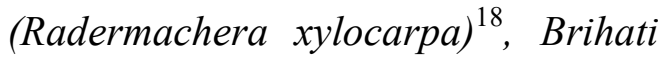
(Solanum indicum Linn.) with Solanum melongena Linn (Brinjal wild species) ${ }^{19}$ and Gokshura (Tribulus terrestris Linn.) with (Acanthospermum hispidum DC $)^{20}$. One more reason for adulteration is vernacular name for example Gambhari (Gmelina arborea) is mistaken with common vernacular name Gambhar (Trevia nudiflora) ${ }^{21}$.

\section{- CONCLUSION:}

Increase demand of Dashmoola in herbal market and scarcity of raw material will lead into the substitution and adulteration of drug, so standardization and authenticity of medicinal plant has declined. Among Dashmoola Even IUCN (International Union for Conservation of Nature) 
enlisted the 3-4 drugs under red list. To overcome such problem NMBP has encouraging the agro techniques of medicinal plant and board also giving $30 \%, \quad 50 \%, \quad 75 \%$ subsidy for the cultivation of medicinal plant. Along with subsidy benefits and WHO's GCP (Good Cultivation Practice) cultivation of such medicinal plant should be done. In future this will increase the quality standards and medicinal value of the Ayurvedic formulations.

\section{REFERENCES}

[1] https://www.researchgate.net/publicat ion/329484793_Depletion_Of_Genui ne_Raw_Drugs_A_Rising_Threat_In _Ayurvedic_Drug_Manufacturing_In dustry

[2] Thakaral K. K.Sushruta Samhita $1^{\text {st }}$ Ed.varanasi: choukhamba orientalia; 2019. p.426

[3] Tripathi Brahmanand. Charak samhita $1^{\text {st }}$ Ed Varanasi: choukhamba orientalia; 2008. P.91

[4] Thakaral K.K. Sushruta Samhita $1^{\text {st }}$ Ed.varanasi: choukhamba orientalia; 2019. p.426

[5] 2.Prof Sharmma.P.Dravyagunasutram $1^{\text {st }}$ Ed Varanasi: choukhamba publications; 2009 p. 120
[6] https://www.apnikheti.com/en/pn/agri culture/horticulture/medicinalplants/indian-bael

[7] 7.https://echarak.in/echarak/templates /Premna\%20integrifolia\%20\%20L..p $\underline{\mathrm{df}}$

[8] https://echarak.in/echarak/templates/ Oroxylum\%20indicum\%20\%20Vent. 24.pdf

[9] https://echarak.in/echarak/templates/S tereospermum $\% 20$ colais\%20(Dillw.) \%20Mabb.pdf

[10] https://echarak.in/echarak/templates/ Gmelina\%20arborea\%20Roxb..pdf

[11] https://echarak.in/echarak/templates/ Solanum\%20indicum\%20\%20Linn.. pdf

[12] https://echarak.in/echarak/templates/ Solanum\%20surattense \%20Burm.\% 20f..pdf

[13] https://echarak.in/echarak/templates/ Uraria\%20picta\%20\%20Desv.pdf

[14] https://echarak.in/echarak/templates/ Desmodium $\% 20$ gangeticum $\% 20 \% 2$ 0(L.)\%20DC.pdf

[15] https://echarak.in/echarak/templates/ Tribulus\%20terrestris\%20Linn..pdf

[16] Prof.chukenar.K.C. Bhavaprakash Nighantu $1^{\text {st }}$ Ed Varanasi: chaukhambha bharati academy; 2013. P. 270 
[17] Prof.chukenar.K.C. Bhavaprakash Nighantu $1^{\text {st }} \quad$ Ed Varanasi: chaukhambha bharati academy; 2013. P. 272

[18] Prof.chukenar.K.C. Bhavaprakash Nighantu $1^{\text {st }} \quad$ Ed Varanasi: chaukhambha bharati academy; 2013. P.267

[19] Prof.chukenar.K.C. Bhavaprakash Nighantu $1^{\text {st }} \quad$ Ed Varanasi: chaukhambha bharati academy; 2013. P.276

[20] Prof.chukenar.K.C. Bhavaprakash Nighantu $1^{\text {st }}$ Ed Varanasi: chaukhambha bharati academy; 2013. P. 279

[21] Prof.chukenar.K.C. Bhavaprakash Nighantu $1^{\text {st }} \quad$ Ed Varanasi: chaukhambha bharati academy; 2013. P.266 